\title{
Comparative study between three Different Doses of Magnesium Sulfate as a Technique of Hypotensive Anesthesia during Functional Endoscopic Sinus Surgery
}

\author{
Hamed A. Sanad, Amgad Z. Mohamed, Ahmed A. Abd-elraouf \\ Department of Anesthesia and Intensive Care, Faculty of Medicine, Al-Azhar University \\ Corresponding author: Ahmed A. Abd-elraouf; Mobile: 010044707637; Email: zizoa3145@gmail.com
}

\begin{abstract}
Background: Hypotensive anesthesia represents a great challenge for the anesthetists. Although, there is great benefit from inducing hypotensive anesthesia, there is a great risk of major morbidity and mortality.

Aim of this work: Evaluation of the optimal dose of $\mathrm{MgSo} 4$ to create hypotension during functional endoscopic sinus surgery.

Materials and methods: This prospective, control, randomized, clinical study was conducted on 60 patient divided into three groups. Patients were recruited from the Department of Anesthesia and Intensive Care, ALAzhar University Hospitals. Each group received different dose of MgSo4 5-10-15 mg/kg/h. Then, we took measures of Bp, Spo2, HR and cortisol. Our observations then were statically analyzed.

Results: There was more stability in hemodynamic parameter in group II and III. There was significant decrease in blood pressure in group III. In addition, there was a decrease in heart rate in group II and III but this decrease wasn't significant. Magnesium sulphate decreased release of stress hormone especially in group III.

Conclusion: Deliberated hypotension is very useful during surgery to decrease time and blood loss. Magnesium sulphate is one of the most useful techniques to induce hypotension during surgical operation. We suggest that using magnesium sulphate in $40 \mathrm{mg} \backslash \mathrm{kg}$ as loading dose then continuous infusion at $15 \mathrm{mg} \mathrm{kg} \backslash \mathrm{h}$ is the most effective and safest technique. Magnesium sulphate is very useful agent to abolish stress response.

Key words: Magnesium Sulfate, Technique, Hypotensive Anesthesiam, Endoscopic Sinus Surgery.
\end{abstract}

\section{INTRODUCTION}

Controlled hypotension (Deliberate hypotension) is an anesthetic technique that permits the clinician to lower arterial blood pressure electively in order to decrease blood loss during surgery and to provide a dry surgical field for the surgeon ${ }^{(1)}$. Deliberate hypotension is an acceptable intraoperative technique for improving surgical condition when a bloodless operative filed is needed together with reduction of blood loss and the need for blood transfusion with its concomitant hazards. In addition, it helps in improving myocardial performance by reducing the preload and after load ${ }^{(2)}$.

Nevertheless, one should avoid the temptation to select any particular blood pressure as the endpoint of hypotensive anesthesia. The minimum acceptable blood pressure must be individualized to each particular patient's intercurrent illness ${ }^{(3)}$.

Normovolemic hypotension can be produced by either a reduction in cardiac output or a decrease in systemic vascular resistance (SVR) (4). Drugs with different modes of action have been used alone or in combination to induce hypotension. These drugs may be classified depending on their mode of action ${ }^{(5)}$. Intravenous magnesium sulphate may be one of the agents used for deliberate hypotension because magnesium intervenes in the activation of membrane calcium
ATP-ase and Na-K ATP-ase involved in trans-membrane ion exchange during depolarization and repolarization phases. Thus, it acts as a stabilizer of cell membrane and intracytoplasmic organelles. Magnesium also exerts its effects on L-type calcium channels in membranes and the sarcoplasmic reticulum by inhibiting the calcium activation depending on the sarcoplasmic channel. Magnesium limits the outflow of calcium from the sarcoplamic reticulum (6). In addition, magnesium sulphate acts as a vasodilator agent by increasing the synthesis of prostacyclin as well as inhibiting angiotensin converting enzyme activity. Also, magnesium sulphate has small dose-dependent myocardial depressant effect ${ }^{(2)}$.

Recently, the antagonistic effect of magnesium at N-methyl-D- aspartate (NMDA) receptors has led to studies of its adjuvant effect in perioperative analgesia ${ }^{(6)}$.

The contraindications of hypotensive anesthesia have relaxed over the years because of better drugs, monitoring, and more experience with the techniques. However, several contraindications must be considered, cerebrovascular disease, liver dysfunction, renal dysfunction, or severe peripheral claudication, which suggest that the patient is less likely to have organ perfusion. Patients with severe anemia and hypovolemia are 
not suitable candidate ${ }^{(2)}$.

The precise incidence of complications with hypotensive anesthesia is difficult to determine but it is usually related to the nervous system, cardiovascular system, renal and postoperative bleeding to the operative side. The decision to induce hypotension during anesthesia should not be made in the operating room without careful considerations of the potential complications ${ }^{(7)}$.

Functional endoscopic sinus surgery is used for treatment of patients with sinus pathology. Intraoperative bleeding reduces visibility in the operative field. General anesthesia is often preferred because of the discomfort and incomplete block that may accompany topical as well as providing hypotensive. ${ }^{(2)}$

Our studies put spot light on magnesium sulphate as a hypotensive agent and made a trial to determine the most suitable dose of it which initiates good hypotensive condition with least complication.

\section{AIM OF THE WORK}

The aim of this study was to evaluate the effect of different doses of magnesium sulphate as hypotensive agent and its optimal dose during functional endoscopic sinus surgery.

\section{PATIENTS AND METHODS}

The study was conducted as a prospective, control, randomized, clinical trial on 60 patients of both sex presented for functional endoscopic sinus surgery. After approval of Medical Committee at the Department of Anesthesia and Intensive Care, ALAzhar University Hospitals. An informed consent was taken from each patient. Patients were randomly classified into 3 groups, 20 patients in each group.

\section{Inclusion criteria:}

Age: 18-60 years old Sex: both sexes ASA I, II

\section{Exclusion criteria:}

1- Pregnancy.

2- Body mass index more than 30 of the ideal.

3- History or laboratory signs of renal or hepatic diseases.

4- Cardiovascular diseases.

5- Neuromuscular diseases.

6- Diabetic neuropathy.

7- Atrio-ventricular block.

8- Known allergy to magnesium sulfate.

9- Morbid obesity.

Patients were selected and grouped by randomized closed envelope technique into three groups; all patients received magnesium sulphate $40 \mathrm{mg} / \mathrm{Kg}$ as an intravenous bolus dose within 10 minutes just before the induction of anaesthesia.

- Group I: $(n=20)$ each patient received magnesium sulphate by intravenous infusion in a rate of $5 \mathrm{mg} / \mathrm{kg} / \mathrm{h}$ during the operation.

- Group II: $(n=20)$ each patient received magnesium sulphate by intravenous infusion in a rate of $10 \mathrm{mg} / \mathrm{kg} / \mathrm{h}$ during the operation.

- Group III: $(n=20)$ each patient received magnesium sulphate by intravenous infusion in a rate of $15 \mathrm{mg} / \mathrm{kg} / \mathrm{h}$ during the operation.

\section{Anaesthesia technique:-}

1- Patients were pre-medicated with Midazolam $0.03 \mathrm{mg} / \mathrm{kg}$ by IV rout.

2- On admission to operating room two peripheral intravenous cannula sizes 18 were inserted.

3- Arterial Teflon cannula size 20 was inserted after application of local anesthetic (lignocaine $2 \%$ ) and after performing of Allans test to the non-dominant hand. Then, the arterial line was connected to the transducer and getting zero at the level of mid axillary line.

4- Routine monitors were connected and base line measurements were recorded. 5- Routine monitor include (Spo2, ECG, NIBP, tempreature, Etco2).

5- 6- Also monitoring of invasive blood pressure, neuromuscular blocking and peak air way pressure.

\section{Induction}

All patients were pre-oxygenated by using face mask for approximately 3 minutes before induction. Anaesthesia was induced using fentanyl $2 \mu \mathrm{g} / \mathrm{kg}$, propofol in a dose of $2 \mathrm{mg} / \mathrm{kg}$ over 20 seconds followed by the muscle relaxant atracuruim besylate $0.5 \mathrm{mg} / \mathrm{kg}$ to facilitate endotracheal intubation. Then Patients were manually ventilated by tight face mask with $100 \%$ $\mathrm{O} 2$ tell complete muscle relaxation was reached and proved by absence train of four by nerve stimulator. Endotracheal intubation was performed by using a suitable endotracheal tube, then double check by auscultation.

\section{Measurement and sampling:-}

The following data were assessed.

1- Heart rate (beats/min).

2- Invasive mean arterial blood pressure $(\mathrm{mm}$ $\mathrm{Hg}$ ).

3- Oxygen saturation.

4- Total amount of muscle relaxant used. These data were measured as follows:

Timing of measurements.

- Before induction.

- Immediately after intubation.

- Four samples taken one every fifteen minutes after intubation 15,30,45,60 minute.

- After 15 minute of stoppage of Mg sulfate.

\section{Statistical analysis}

Results were collected and tabulated and 
analyzed by SPSS (SPSS Inc, CHICAG,Inc,USA). Quantitative data were expressed as mean and standard of deviation $(\mathrm{X}+\mathrm{SD})$ and analyzed by applying student t-test for comparison of three groups of normal distributed variables. Chi square test was used to compare qualitative variables between groups. Paired t-test was used for comparison of before and after observation in the same group. Level of significance was set as $\mathrm{P}$ value $>0.005$ denotes statically insignificant $\mathrm{P}$ value $<0.05$ denotes statistically significant.

\section{RESULTS}

This study included 60 patient scheduled for functional endoscopic sinus surgery. They were randomly assigned to three group. All patients receive magnesium sulfate $40 \mathrm{mg} / \mathrm{kg}$ as a loading dose. Then, each group receive different dose of magnesium sulfate as maintained continuous infusion dose (group I received $5 \mathrm{mg} / \mathrm{kg} / \mathrm{h}$, group II received $10 \mathrm{mg} / \mathrm{kg} / \mathrm{h}$ and group III received 15 $\mathrm{mg} / \mathrm{kg} / \mathrm{h}$ ).

\section{1) Demographic data.}

Patients in the three studied groups were well matched for age, sex and mean of body weight.

In group (I) the mean age was $33.05 \pm 11.49$ years, while in group (II) the mean age was $36.8 \pm$

9.0 years and in group (III) mean age was 34.05 $\pm 9,9$ years. Regarding male to female ratio,

it was 10:10, 11: 9, 9:11 in group I, II, III respectively. The average weight was $82.75 \pm$

$9.25(\mathrm{~kg}), 79.15 \pm 7.82(\mathrm{~kg})$ and $78.55 \pm 9.27$ $(\mathrm{kg})$ in group I, II, III respectively.

- There was no statistically significant difference among the three group $(\mathrm{P}>0.05)$.

Table (1): Demographic data of the patients in the three groups.

\begin{tabular}{|c|c|c|c|c|}
\hline Demographic data & $\begin{array}{c}\text { Group (I) } \\
(\text { Mean } \pm \text { SD) } \mathbf{N}=\mathbf{2 0} \\
\end{array}$ & $\begin{array}{c}\text { Group (II) } \\
(\text { Mean } \pm \text { SD) } N=20 \\
\end{array}$ & $\begin{array}{c}\text { Group (III) } \\
\text { Mean } \pm \text { D) } \mathbf{N}=\mathbf{2 0}\end{array}$ & $P$ value \\
\hline Age (years) & $33.05 \pm 11.49$ & $36.8 \pm 9.0$ & $34.05 \pm 9.9$ & $\begin{array}{c}\mathrm{P}>0.05 \\
(0.28)\end{array}$ \\
\hline Sex: Male/Female & $10 / 10$ & $11 / 9$ & $9 / 11$ & $\begin{array}{c}\mathrm{P}>0.05 \\
(0.45)\end{array}$ \\
\hline Body weight & $82.75 \pm 9.25$ & $79.15 \pm 7.8$ & $78.55 \pm 9.27$ & $\begin{array}{c}\mathrm{P}>0.05 \\
(0.35)\end{array}$ \\
\hline
\end{tabular}

$\mathrm{P}$ value $<0.05$ is significant

\section{2) Time changes in haemodynamic parameters (Mean of heart rate, Mean arterial blood pressure).}

a) Mean of Heart rate beats / $\min$ (Tables 2, 3 and 4)

As regards heart rate in group (I), there was a slight increase in HR just after intubation (Immediate reading $(80.41 \pm 7.21))$ then there was minimal decrease in the next readings $(15,30,45$ and 60 minutes readings) (78.62 $\pm 6.3-78.37 \pm 3.6-76.25 \pm 4.9-75.63 \pm 4.11)$, but there was slight increase in HR after 15 minutes of extubation. There was no statistically significant decrease in mean of heart rate in group (I) at any reading compared to preoperative reading $(\mathrm{P}$ value $>0.05$ ).

Table (2): Changes in the mean of heart rate (beats/min.) in group (I):

\begin{tabular}{||c|c|c|c|c|c|c|c|c||}
\hline \hline Time & Preoperative & Immediately & 15min & 30min & 45min & 60min & $\begin{array}{c}\text { after15 } \\
\text { min }\end{array}$ & P1 value \\
\hline \hline HRMean \pm & 79.34 & 80.41 & 78.62 & 78.37 & 76.25 & 75.63 & 79.61 & \\
$\begin{array}{c}\text { SD } \\
\text { (beats/min) }\end{array}$ & \pm 7.3 & \pm 7.21 & \pm 6.3 & \pm 3.6 & \pm 4.9 & \pm 4.11 & \pm 4.17 & \multirow{2}{*}{$\mathbf{0 . 0 5 ( 0 . 2 8 )}$} \\
\cline { 1 - 6 } P2 Value & & $>0.05$ & $>0.05$ & $>0.0$ & $>0.0$ & $>0.0$ & $>0.0$ & \\
\hline
\end{tabular}

$\mathrm{P}$ value $<0.05$ is significant

P1: Between all readings of the group P2: for each reading in relation to the base line of each group.

As regards heart rate in group (II), there was a decrease in HR just after intubation (Immediate reading (76.62 \pm 8.4$)$, then there was decrease in the next readings $(15,30,45$ and 60 readings $)(78.09 \pm 3.48,78.18 \pm$ $3.8,74.24 \pm 8.9$ and $76.05 \pm 4.2$ respectively). However, there was a slight decrease in HR after 15 minute of extubation in comparison with preoperative reading. 
Table (3): Changes in the mean of heart rate (beats/min.) in group (II)

\begin{tabular}{|c|c|c|c|c|c|c|c|c|}
\hline Time & Preoperative & Immediately & $15 \mathrm{~min}$ & 30min & $45 \mathrm{~min}$ & $60 \mathrm{~min}$ & $\begin{array}{c}\text { after15 } \\
\text { min }\end{array}$ & P1 value \\
\hline $\begin{array}{l}\text { HR } \\
\text { Mean } \pm \text { SD } \\
\text { (beats/min) }\end{array}$ & $\begin{array}{l}82.41 \\
\pm 9.1\end{array}$ & $\begin{array}{l}76.62 \\
\pm 4.9\end{array}$ & $\begin{array}{c}78.09 \pm \\
3.84\end{array}$ & $\begin{array}{c}78.18 \pm \\
3.84\end{array}$ & $\begin{array}{c}74.24 \pm \\
4.9\end{array}$ & $\begin{array}{c}76.05 \pm \\
4.2\end{array}$ & $\begin{array}{c}79.67 \pm \\
4.8\end{array}$ & \multirow{2}{*}{$\begin{array}{l}>0.05 \\
(0.65)\end{array}$} \\
\hline P2 Value & & $\begin{array}{l}>0.05 \\
(0.55)\end{array}$ & $\begin{array}{l}>0.05 \\
(0.25)\end{array}$ & $\begin{array}{l}>0.05 \\
(0.23)\end{array}$ & $\begin{array}{l}>0.05 \\
(0.45)\end{array}$ & $\begin{array}{l}>0.05 \\
(0.95)\end{array}$ & $\begin{array}{l}>0.05 \\
(0.30)\end{array}$ & \\
\hline
\end{tabular}

\section{$P$ value $<0.05$ is significant}

P1: Between all readings of the group P2: for each reading in relation to the base line of each group.

As regards to heart rate in group (III), There was a decrease in HR just after intubation immediately (77.80 \pm 4.4 ) and decrease in the next readings $(15,30,45$ and 60 minutes readings). However, there was slight increase in HR 15 after extubation as compared to pre-operative reading as shown in table (3).

Table (4): Changes in the mean of heart rate (beats/min.) in group (III).

\begin{tabular}{|c|c|c|c|c|c|c|c|c|}
\hline Time & Preoperative & Immediately & $15 \mathrm{~min}$ & 30min & $45 \mathrm{~min}$ & $60 \mathrm{~min}$ & $\begin{array}{c}\text { after15 } \\
\text { min }\end{array}$ & P1 value \\
\hline $\begin{array}{l}\text { HR } \\
\text { Mean } \pm \text { SD } \\
\text { (beats } / \text { min) }\end{array}$ & $80.71 \pm 7.66$ & $77.80 \pm 4.4$ & $\begin{array}{c}76.21 \pm \\
6.22\end{array}$ & $\begin{array}{l}75.34 \pm \\
5.75\end{array}$ & $\begin{array}{c}75.52 \pm \\
4.91\end{array}$ & $\begin{array}{c}74.17 \pm \\
4.1\end{array}$ & $\begin{array}{c}76.34 \pm \\
3.9\end{array}$ & \multirow{2}{*}{$\begin{array}{l}<0.05 \\
(0.25)\end{array}$} \\
\hline P2 Value & & $\begin{array}{l}>0.05 \\
(0.35)\end{array}$ & $\begin{array}{l}>0.05 \\
(0.55)\end{array}$ & $\begin{array}{l}>0.05 \\
(0.15)\end{array}$ & $\begin{array}{l}>0.05 \\
(0.36)\end{array}$ & $\begin{array}{l}>0.05 \\
(0.65)\end{array}$ & $\begin{array}{l}>0.05 \\
(0.36)\end{array}$ & \\
\hline
\end{tabular}

$P$ value $<0.05$ is significant

P1: Between all readings of the group P2: for each reading in relation to the base line of each group.

- Comparison between three studied groups regarding mean heart rate.

Concerning heart rate, when we compared between the three groups at each reading. We noticed that there was decrease in heart rate immediately after intubation in group (II) and (III) but there was no decrease in heart rate at this timing in group (I). In the following readings, there was a decrease in heart rate in group III more than in group II more than in group I reading (15,30,45and 60 reading). 15 minutes after extubation, there was an increase in heart rate in group III less than in group II less than in group I as shown in table (5). There was no statistically significant difference between the three groups in heart rate at any time of measurements, but we noticed that in group III there was the most decrease in the mean of heart rate.

Table (5): Comparison between three studied groups regarding in the mean of heart rate (beats $/ \mathrm{min}$.)

\begin{tabular}{||l|c|c|c|c||}
\hline \multicolumn{1}{|c|}{ Time } & $\begin{array}{c}\text { group(I) (Mean } \\
\mathbf{\pm S D} \\
\mathbf{N = 2 0}\end{array}$ & $\begin{array}{c}\text { group(II) (Mean } \pm \\
\mathbf{S D}) \\
\mathbf{N = 2 0}\end{array}$ & $\begin{array}{c}\text { group(III) (Mean } \\
\mathbf{\pm} \mathbf{D}) \\
\mathbf{N = 2 0}\end{array}$ & P value \\
\hline \hline Preoperative & $79.34 \pm 7.32$ & $82.41 \pm 9.15$ & $80.71 \pm 7.66$ & $\begin{array}{c}>0.05 \\
(0.35)\end{array}$ \\
\hline Immediately & $80.45 \pm 7.21$ & $76.62 \pm 7.82$ & $77.80 \pm 4.42$ & $\begin{array}{c}>0.05 \\
(0.36)\end{array}$ \\
\hline 15 min & $78.62 \pm 6.30$ & $78.09 \pm 3.84$ & $76.21 \pm 6.26$ & $\begin{array}{c}>0.05 \\
(0.25)\end{array}$ \\
\hline 30 min & $78.37 \pm 3.62$ & $78.18 \pm 4.23$ & $75.34 \pm 5.75$ & $\begin{array}{c}>0.05 \\
(0.65)\end{array}$ \\
\hline 45 min & $76.25 \pm 4.98$ & $74.24 \pm 4.90$ & $75.52 \pm 4.91$ & $\begin{array}{c}>0.05 \\
(0.20)\end{array}$ \\
\hline 60 min & $75.63 \pm 4.11$ & $76.05 \pm 4.2$ & $74.17 \pm 4.11$ & $\begin{array}{c}>0.05 \\
(0.35)\end{array}$ \\
\hline after15 min & $79.61 \pm 4.17$ & $79.60 \pm 4.8$ & $76.34 \pm 3.90$ & $\begin{array}{c}>0.05 \\
(0.68)\end{array}$ \\
\hline
\end{tabular}

b) Mean of Blood Pressure (mmHg) table (6,7 and 8): 
As regards the mean of blood pressure in group (I), there was a slight increase in blood pressure just after intubation (Immediate reading $(93.22 \pm 9.77)$, then there was minimal decrease in the next readings $(15$, 30,45 and 60 readings). However, there was slight increase in mean of blood pressure after 15 of extubation. (Preoperative (92.12 \pm 7.7 ) but 15 min after extubation (94.33 \pm 6.34$)$, which was insignificant.

Table (6): Changes in the mean of mean of blood pressure ( $\mathrm{mmHg}$ ) in group (I)

\begin{tabular}{|c|c|c|c|c|c|c|c|c|}
\hline Time & Preoperative & Immediately & $15 \mathrm{~min}$ & 30min & $45 \mathrm{~min}$ & $60 \mathrm{~min}$ & $\begin{array}{c}\text { after15 } \\
\text { min }\end{array}$ & $\begin{array}{c}\text { P1 } \\
\text { value }\end{array}$ \\
\hline $\begin{array}{c}\text { MABP Mean } \pm \\
\text { SD } \\
\text { mmHg } \\
\end{array}$ & $92.12 \pm 7.7$ & $93.22 \pm 9.77$ & $\begin{array}{c}88.21 \pm \\
6.78\end{array}$ & $\begin{array}{c}86.11 \pm \\
5.9\end{array}$ & $\begin{array}{c}85.13 \pm \\
4.82\end{array}$ & $\begin{array}{c}87.09 \pm \\
4.82\end{array}$ & $\begin{array}{c}94.33 \pm \\
6.34\end{array}$ & \multirow{2}{*}{$\begin{array}{l}>0.05 \\
(0.28)\end{array}$} \\
\hline P2 Value & & $\begin{array}{l}>0.05 \\
(0.26)\end{array}$ & $\begin{array}{l}>0.05 \\
(0.34)\end{array}$ & $\begin{array}{l}>0.05 \\
(0.15)\end{array}$ & $\begin{array}{l}>0.05 \\
(0.25)\end{array}$ & $\begin{array}{l}>0.05 \\
(0.35)\end{array}$ & $\begin{array}{l}>0.05 \\
(0.45)\end{array}$ & \\
\hline
\end{tabular}

$P$ value $<0.05$ is significant

P1: Between all readings of the same group P2: for each reading in relation to the base line of each group.

In regard to blood pressure in group (II). there was a decrease in blood pressure just after intubation (Immediate reading $(86.13 \pm 8.86)$, then there was decrease in the next readings $(15,30,45$ and 60 readings) $(78.23 \pm 8.5,79.54 \pm 7.59,78.71 \pm 5.95$ and $79.35 \pm 6.9$ respectively). However, there was no increase in blood pressure after 15 of extubation as compared to pre-operative reading. (Pre-operative $(91.43 \pm 9.3)$ but $15 \mathrm{~min}$ after extubation $(86.78 \pm 7.8)$.

Table (7): Changes in the mean of mean of blood pressure (mmHg) in group (II)

\begin{tabular}{|c|c|c|c|c|c|c|c|c|}
\hline Time & Preoperative & Immediately & $15 \mathrm{~min}$ & 30min & $45 \mathrm{~min}$ & $60 \mathrm{~min}$ & $\begin{array}{c}\text { after15 } \\
\text { min }\end{array}$ & $\begin{array}{c}\text { P1 } \\
\text { Value }\end{array}$ \\
\hline $\begin{array}{c}\text { MABP } \\
\text { Mean } \pm \\
\text { SD } \\
\text { mmHg } \\
\end{array}$ & $91.43 \pm 9.3$ & $86.13 \pm 8.86$ & $\begin{array}{c}78.23 \pm \\
8.5\end{array}$ & $\begin{array}{c}79.54 \pm \\
7.59\end{array}$ & $\begin{array}{c}78.71 \pm \\
5.95\end{array}$ & $\begin{array}{c}79.35 \pm \\
6.9\end{array}$ & $\begin{array}{c}86.78 \pm \\
7.8\end{array}$ & \multirow[t]{2}{*}{$\begin{array}{l}>0.05 \\
(0.14)\end{array}$} \\
\hline P2 Value & & $\begin{array}{l}>0.05 \\
(0.45)\end{array}$ & $\begin{array}{l}>0.05 \\
(0.34)\end{array}$ & $\begin{array}{l}>0.05 \\
(0.34)\end{array}$ & $\begin{array}{l}>0.05 \\
(0.47)\end{array}$ & $\begin{array}{l}>0.05 \\
(0.34)\end{array}$ & $\begin{array}{l}>0.05 \\
(0.47)\end{array}$ & \\
\hline
\end{tabular}

P1: Between all readings of the same group P2: for each reading in relation to the base line of each group.

Regarding blood pressure in group (III), there was a decrease in blood pressure just after intubation (Immediate reading $(80.34 \pm 8.8)$, then there was decrease in the next readings $(15,30,45$ and 60 readings), but there was no increase in blood pressure after 15 minutes of extubation in comparison to pre-operative reading as shown in table (8).

Table (8): Changes in the mean of mean of blood pressure (mmHg) in group (III)

\begin{tabular}{|c|c|c|c|c|c|c|c|c|}
\hline Time & Preoperative & Immediately & $15 \mathrm{~min}$ & 30min & $45 \mathrm{~min}$ & $60 \mathrm{~min}$ & $\begin{array}{c}\text { after15 } \\
\text { min }\end{array}$ & $\begin{array}{c}\text { P1 } \\
\text { value }\end{array}$ \\
\hline $\begin{array}{c}\text { MABP } \\
\text { Mean } \pm \text { SD } \\
\text { mmHg }\end{array}$ & $90.15 \pm 9.3$ & $80.34 \pm 8.8$ & $\begin{array}{c}75.76 \pm \\
8.5\end{array}$ & $\begin{array}{c}74.23 \pm \\
7.5\end{array}$ & $\begin{array}{c}73.64 \pm \\
5.9 @\end{array}$ & $\begin{array}{c}73.32 \pm \\
6.9 @\end{array}$ & $\begin{array}{c}78.61 \pm \\
7.8\end{array}$ & \multirow{2}{*}{$\begin{array}{l}<0.05 \\
(0.04)\end{array}$} \\
\hline P2 Value & & $\begin{array}{l}>0.05 \\
(0.36)\end{array}$ & $\begin{array}{l}>0.05 \\
(0.22)\end{array}$ & $\begin{array}{l}>0.05 \\
(0.34)\end{array}$ & $\begin{array}{l}<0.05 \\
(0.01)\end{array}$ & $\begin{array}{l}<0.05 \\
(0.03)\end{array}$ & $\begin{array}{l}>0.05 \\
(0.15)\end{array}$ & \\
\hline
\end{tabular}

P1: Between all readings of the same group P2: for each reading in relation to the base line of each group. @: significant values

- Comparison between three studied groups as regards mean BP (table 9)

Regarding the mean of mean blood pressure, we noticed that there was decrease in mean blood pressure immediately after intubation in group (II) and (III) but there is increase in mean blood pressure at this timing in group (I). In the following readings we found that there was decrease in mean blood pressure in group (III) more than in group (II) more than in group (I) reading (15,30,45and 60 reading). After extubation (15 after reading), there was a decrease in mean blood pressure in group (III) more than in group (II) more than in group (I). However, there was statistically significant difference between the three groups in mean blood pressure at 45 and 60 min measurements. 
Table (9): Comparison between three studied groups as regard the mean of mean of blood pressure (mmHg).

\begin{tabular}{||c|c|c|c|c||}
\hline \multicolumn{1}{|c|}{ Time } & $\begin{array}{c}\text { (I) group (Mean } \\
\mathbf{\pm S D} \\
\mathbf{N = 2 0}\end{array}$ & $\begin{array}{c}\text { (II) group (Mean } \pm \\
\mathbf{S D}) \\
\mathbf{N = 2 0}\end{array}$ & $\begin{array}{c}\text { (III) group } \\
\text { (Mean } \pm \mathbf{D}) \\
\mathbf{N = 2 0}\end{array}$ & P value \\
\hline \hline Preoperative & $92.12 \pm 7.7$ & $91.43 \pm 9.3$ & $90.15 \pm 9.52$ & $\begin{array}{c}>0.05 \\
(0.47)\end{array}$ \\
\hline Immediately & $93.22 \pm 9.77$ & $86.13 \pm 8.86$ & $80.34 \pm 8.71$ & $\begin{array}{c}>0.05 \\
(0.36)\end{array}$ \\
\hline $\mathbf{1 5}$ min & $88.21 \pm 6.78$ & $78.23 \pm 8.57$ & $75.76 \pm 8.54$ & $\begin{array}{c}>0.05 \\
(0.78)\end{array}$ \\
\hline $\mathbf{3 0}$ min & $86.11 \pm 5.95$ & $79.54 \pm 7.59$ & $74.23 \pm 8.73$ & $\begin{array}{c}>0.05 \\
(0.34)\end{array}$ \\
\hline $\mathbf{4 5}$ min & $85.13 \pm 6.73$ & $78.71 \pm 5.95$ & $73.64 \pm 7.23$ & $\begin{array}{c}<0.05 \\
(0.02)\end{array}$ \\
\hline $\mathbf{6 0}$ min & $87.09 \pm 4.82$ & $79.35 \pm 6.93$ & $73.32 \pm 7.99$ & $\begin{array}{c}<0.05 \\
(0.03)\end{array}$ \\
\hline after 15 min & $94.33 \pm 6.34$ & $86.78 \pm 7.87$ & $78.61 \pm 7.84$ & $\begin{array}{c}>0.05 \\
(0.33)\end{array}$ \\
\hline
\end{tabular}

3) Time changes in oxygen saturation (tables 10, 11 and 12).

Concerning the mean of oxygen saturation in group (I), there was a slight insignificant decrease in mean of oxygen saturation just after intubation, then there was no significant change in all other readings as compared to pre-operative reading as shown in table (10).

$\mathbf{T}$

able (10): Changes in the mean of $\mathrm{O}_{2}$ saturation (\%) in the group (I)

\begin{tabular}{|c|c|c|c|c|c|c|c|c|}
\hline Time & Preoperative & Immediately & $\begin{array}{c}15 \\
\text { min }\end{array}$ & $\begin{array}{c}30 \\
\text { min }\end{array}$ & 45min & $60 \mathrm{~min}$ & $\begin{array}{c}\text { after15 } \\
\text { min }\end{array}$ & $\begin{array}{c}\text { P1 } \\
\text { value }\end{array}$ \\
\hline $\begin{array}{ll}\text { Mean } & \pm \\
\text { SD O O}_{2} \% & \\
\end{array}$ & $99.01 \pm 0.5$ & $98.02 \pm 0.51$ & $\begin{array}{c}99.21 \pm \\
0.71 \\
\end{array}$ & $\begin{array}{l}99.01 \\
\pm 0.95 \\
\end{array}$ & $\begin{array}{r}99.34 \\
\pm 0.62 \\
\end{array}$ & $\begin{array}{r}99.04 \\
\pm 0.64 \\
\end{array}$ & $\begin{array}{c}99.01 \pm \\
0.67 \\
\end{array}$ & \multirow[t]{2}{*}{$\begin{array}{l}>0.05 \\
(0.65)\end{array}$} \\
\hline P2 Value & & $\begin{array}{l}>0.05 \\
(0.65)\end{array}$ & $\begin{array}{l}>0.05 \\
(0.34)\end{array}$ & $\begin{array}{l}>0.05 \\
(0.68)\end{array}$ & $\begin{array}{l}>0.05 \\
(0.45)\end{array}$ & $\begin{array}{l}>0.05 \\
(0.25)\end{array}$ & $\begin{array}{l}>0.05 \\
(0.36)\end{array}$ & \\
\hline
\end{tabular}

$P$ value $<0.05$ is significant

P1: Between all readings of the same group P2: for each reading in relation to the base line of each group.

About mean of oxygen saturation in group (II), there was a slight insignificant decrease in mean of oxygen saturation just after intubation, then there was no significant change in all other readings as compared to preoperative reading as shown in table (11).

Table (11): Changes in the mean of $\mathrm{O}_{2}$ saturation (\%) in the group (II)

\begin{tabular}{|c|c|c|c|c|c|c|c|c||}
\hline Time & Preoperative & Immediately & $\begin{array}{c}\mathbf{1 5} \\
\text { min }\end{array}$ & $\begin{array}{c}\text { 30 } \\
\text { min }\end{array}$ & 45min & 60min & $\begin{array}{c}\text { after15 } \\
\text { min }\end{array}$ & $\begin{array}{c}\text { P1 } \\
\text { value }\end{array}$ \\
\hline \hline $\begin{array}{c}\text { Mean } \pm \mathrm{SD} \\
\mathrm{O}_{2} \%\end{array}$ & \multirow{2}{*}{$99.10 \pm 0.56$} & \multirow{2}{*}{$99.03 \pm 0.59$} & $\begin{array}{c}98.20 \\
\pm 0.51\end{array}$ & $\begin{array}{c}98.12 \\
\pm 0.69\end{array}$ & $\begin{array}{c}98.32 \\
\pm .51\end{array}$ & $\begin{array}{c}98.41 \\
\pm 0.56\end{array}$ & $\begin{array}{c}97.65 \pm \\
0.4\end{array}$ & $>0.05$ \\
\cline { 1 - 6 } $\mathrm{P} 2$ Value & & $>0.05$ & $>0.05$ & $>0.05$ & $>0.05$ & $>0.05$ & $>0.05$ & $(0.35)$ \\
$(0.34)$ & $(0.85)$ & $(0.34)$ & $(0.48)$ & $(0.35)$ & $(0.55)$ & \\
\hline
\end{tabular}

$P$ value $<0.05$ is significant

P1: Between all readings of the same group P2: for each reading in relation to the base line of each group.

In regards to mean of oxygen saturation in group (III), there was a slight insignificant decrease in mean of oxygen saturation just after intubation, then there was no significant change in all other readings as compared to pre-operative reading as shown in table (12). 
Table (12): Changes in the mean of $\mathrm{O}_{2}$ saturation (\%) in the group (III)

\begin{tabular}{|c|c|c|c|c|c|c|c|c||}
\hline Time & Preoperative & Immediately & $\begin{array}{c}\mathbf{1 5} \\
\text { min }\end{array}$ & $\begin{array}{c}\text { 30 } \\
\text { min }\end{array}$ & 45min & 60min & $\begin{array}{c}\text { after15 } \\
\text { min }\end{array}$ & $\begin{array}{c}\text { P1 } \\
\text { value }\end{array}$ \\
\hline \hline $\begin{array}{c}\text { Mean } \pm \text { SD } \\
\mathbf{O}_{2}\end{array}$ & \multirow{2}{*}{$99.20 \pm 0.56$} & $99.14 \pm 0.59$ & 98.05 & 98.07 & 98.28 & 98.31 & $97.02 \pm$ & $>0.05$ \\
& & $>0.51$ & \pm 0.69 & \pm 0.51 & \pm 0.56 & 0.4 & $(0.64)$ \\
\hline P2 value & & $>0.05$ & $>0.05$ & $>0.05$ & $>0.05$ & $>0.05$ & $>0.05$ & \\
& & $(0.34)$ & $(0.36)$ & $(0.98)$ & $(0.64)$ & $(0.35)$ & $(0.37)$ & \\
\hline
\end{tabular}

$P$ value $<0.05$ is significant

P1: Between all readings of the same group P2: for each reading in relation to the base line of each group.

- Changes in $\mathbf{O}_{2}$ in the three suited groups (Table 13)

As regards mean of mean of blood oxygen saturation, we notice that there was decrease in mean of blood oxygen saturation immediately after intubation in group (I), (II) and (III). In the following readings, we found that there was decrease in mean of blood oxygen saturation in group (III) more than in group (II) more than in group (I) readings. After extubation, there was decrease in mean of blood oxygen saturation in group (III) more than in group (II) more than in group (I). However all changes were insignificant as shown in table (13).

Table (13): Changes in the mean of $\mathrm{Sa} \mathrm{O} 2(\%)$ in the three groups:

\begin{tabular}{|c|c|c|c|c||}
\hline Time & $\begin{array}{c}\text { group(I) } \\
(\text { Mean } \pm \text { SD) N } \mathbf{2 0}\end{array}$ & $\begin{array}{c}\text { group(II) } \\
(\text { Mean } \pm \text { SD) } \mathbf{N}=\mathbf{2 0}\end{array}$ & $\begin{array}{c}\text { ) group(III) } \\
\text { Iean } \pm \text { SD) } \mathbf{N}=\mathbf{2 0}\end{array}$ & P value \\
\hline \hline Preoperative & $99.02 \pm 0.5$ & $99.10 \pm 0.73$ & $99.20 \pm 0.56$ & $\begin{array}{c}>0.05 \\
(0.37)\end{array}$ \\
\hline Immediately & $98.31 \pm 0.514$ & $99.03 \pm 0.85$ & $99.14 \pm 0.59$ & $\begin{array}{c}>0.05 \\
(0.98)\end{array}$ \\
\hline 30 min & $99.21 \pm 0.71$ & $98.20 \pm 0.71$ & $98.05 \pm 0.51$ & $\begin{array}{c}>0.05 \\
(0.87)\end{array}$ \\
\hline $\mathbf{4 5}$ min & $99.01 \pm 0.95$ & $98.12 \pm 0.85$ & $98.07 \pm 0.69$ & $\begin{array}{c}>0.05 \\
(0.95)\end{array}$ \\
\hline $\mathbf{6 0}$ min & $99.34 \pm 0.62$ & $98.32 \pm 0.51$ & $98.28 \pm 0.51$ & $\begin{array}{c}>0.05 \\
(0.47)\end{array}$ \\
\hline $\mathbf{7 5}$ min & $99.04 \pm 0.64$ & $98.41 \pm 0.51$ & $98.31 \pm 0.56$ & $\begin{array}{c}>0.05 \\
(0.69)\end{array}$ \\
\hline After 15 min & $99.01 \pm 0.67$ & $97.65 \pm 0.85$ & $97.02 \pm 0.4$ & $\begin{array}{c}>0.05 \\
(0.55)\end{array}$ \\
\hline
\end{tabular}

$P$ value $<0.05$ is significant

P: for each reading between three groups.

4) Total dose of muscle relaxant (mg) used in the three studied groups.

As regards mean of total muscle relaxant dose, we noticed that the mean dose of muscle relaxant needed in group (III) was less than the dose needed in group (II) and group (I). There was no statistically significant difference between the three groups as shown in table (14).

Table (14): Mean of total muscle relaxant dose (mg) in three groups:-

\begin{tabular}{||l|c|c|c|c||}
\hline \hline & $\begin{array}{c}\text { Group(I) } \\
(\text { Mean } \pm \text { SD) } \mathbf{N}= \\
20\end{array}$ & $\begin{array}{c}\text { Group (II) } \\
(\text { Mean } \pm \text { SD) } N= \\
20\end{array}$ & $\begin{array}{c}\text { Group (III) } \\
(\text { Mean } \pm \text { D) N = 20 }\end{array}$ & P value \\
\hline $\begin{array}{l}\text { Mean of total dose of } \\
\text { muscle relaxant (mg) } \\
\text { Mean } \pm \text { SD) }\end{array}$ & $110.56 \pm 0.57$ & $105.43 \pm 0.94$ & $95.89 \pm 0.54$ & $\begin{array}{c}>0.05 \\
(0.89)\end{array}$ \\
\hline
\end{tabular}

$\mathrm{P}$ value $<0.05$ is significant

\section{DISCUSSION}

Magnesium sulphate may be one of the agents used for deliberate hypotension because magnesium intervenes in the activation of membrane calcium ATPase and Na-K ATPase involved in trans-membrane ion exchange during depolarization and repolarization phases. Thus it acts as a stabilizer of cell membrane and 
intracytoplasmic organelles. Magnesium also exerts its effects on L-type calcium channels in membranes and the sarcoplasmic reticulum by inhibiting calcium activation depending on the sarcoplasmic channel where magnesium limits the outflow of calcium from the sarcoplamic reticulum (6).

Magnesium sulphate acts as a vasodilator agent by increasing the synthesis of prostacyclin as well as inhibiting angiotensin converting enzyme activity. Magnesium sulphate is a vasodilator with minimal myocardial depression (2). Recently, the antagonistic effect of magnesium at N-methyl-Daspartate (NMDA) receptors led to study its adjuvant effects in perioperative analgesia ${ }^{(6)}$.

This present study was to evaluate magnesium sulphate as a hypotensive anaesthesia technique in three different doses. The studied groups received magnesium sulphate $40 \mathrm{mg} / \mathrm{kg}$ as a slow IV bolus in a $10 \mathrm{~min}$ period before the induction of anaesthesia in all groups. Then, 5 $\mathrm{mg} / \mathrm{kg} / \mathrm{h}$ by continuous IV infusion during the operation in group (I), $10 \mathrm{mg} / \mathrm{Kg} / \mathrm{h}$ in group (II) and $15 \mathrm{mg} / \mathrm{kg} / \mathrm{h}$ in group (III).

Using $40 \mathrm{mg} / \mathrm{kg}$ as loading dose and 15 $\mathrm{mg} / \mathrm{kg}$ as maintained dose of magnesium in group III to produce hypotension was tried before by Elsharnouby and Elsharnouby ${ }^{(8)}$. They reported a steady and smooth reduction in MAP and heart rate, with no episodes of severe hypotension. No patient had rebound hypertension when magnesium sulphate infusion was stopped, which could occur with hypotensive anaesthesia techniques using arterial vasodilators.

Also, use of magnesium to produce hypotension is used before by Sanders and Sim ${ }^{(9)}$ who made a study in patients undergoing major oral and maxillofacial surgery, where magnesium was given at a rate of $40 \mathrm{mg} / \mathrm{kg} / \mathrm{h}$ after induction until the MAP reached $55 \mathrm{~mm} \mathrm{Hg}$, followed by a maintenance dose of $5 \mathrm{mg} / \mathrm{kg} / \mathrm{h}$ until $30 \mathrm{~min}$ before the end of surgery, without loss of the hypotensive effect. There was significant decrease in blood pressure as compared to the base line.

Larger dose was reported by Crozier $\boldsymbol{e t}$ al. (10) who made a study on patients who were undergoing cerebral-aneurysm clipping, an initial magnesium sulphate dose of $40 \mathrm{mg} / \mathrm{kg}$ was used until MAP of $70 \mathrm{~mm} \mathrm{Hg}$ was reached, then they used $20 \mathrm{mg} / \mathrm{kg} / \mathrm{h}$ as maintainance dose until the target MAP was reached, and then $10 \mathrm{mg} / \mathrm{kg} / \mathrm{h}$ for the remaining time.

On the other hand Akazawa et al. ${ }^{(11)}$ used magnesium sulphate during sevoflurane anaesthesia at larger doses even more than 120 $\mathrm{mg} / \mathrm{kg}$. They concluded that magnesium did not have a deleterious effect on atrioventricular (AV) conduction time and surface ECG during 1 minimal alveolar concentration (MAC) of sevoflurane and recommended the use of high doses of magnesium sulphate in patients with cardiac arrhythmia and hypertension during sevoflurane anaesthesia.

In this study and in other studies, all of them used the changes in heart rate, arterial blood pressure and blood level of stress hormon (adrenalin and cortisol) as indicators to evaluate these doses of magnesium sulphate.

Regarding heart rate, there was an increase in heart rate in group (I) just in response to intubation and then there was minimal decrease in the next readings but an increase in HR after 15 of extubation was reported without statistical significance. In group (II), there was gradual decrease in HR and then there was gradual decrease in HR in all readings except slight increase in HR after 15 of extubation in comparison with preoperative reading. In group (III), a decrease in HR after intubation and in the next readings but there was slight increase in HR after $15 \mathrm{~min}$ of extubation in compared to pre-operative reading. All these changes were non-significant.

The pattern in each group, group (I) showed no significant decrease along the time of operation but fluctuation between readings is minimal with increase after extubation after stoppage of $\mathrm{MgSo} 4$ (rebound tachycardia). But in group (II) and (III), the pattern of decrease in heart rate with time was noticed and it was more marked in group (III). In addition, an increase after stoppage of MgSo4 infusion in relation to base line (no rebound tachycardia). This agreed with ELSharnouby and Elsharnouby (8) who used 15 $\mathrm{mg} / \mathrm{kg} / \mathrm{h}$ as maintained dose and found that this dose was effective to reduce heart rate.

Also the ability of magnesium to abolish the tachycardic response of intubation was discussed by the study done by Ludbrook et al. ${ }^{(12)}$ where they looked at cardiovascular responses associated with tracheal intubation in 15 patients who were pre-treated with $60 \mathrm{mg} / \mathrm{kg}$ body weight magnesium sulphate IV and in 15 control patients a saline solution pre-treatment. In magnesiumpretreated group, the increase in heart rate was less than the control group.

Heart rate is an important indicator for blood pressure. As blood pressure equal cardiac output multiplied by peripheral resistance but cardiac out but equal heart rate multiplied by stork volume, so decrease in blood pressure usually accompanied by increase in heart rate to keep fixed cardiac output. This reflex is attenuated by magnesium sulphate as it intervenes in the activation of membrane calcium ATPase and Na-K 
ATPase involved in trans-membrane ion exchange during depolarization and repolarization phases, and thus acts as a stabilizer of myocardial cell membrane and intracytoplasmic organelles ${ }^{(13)}$. Also magnesium sulphate has small, dose dependent myocardial depressant effect ${ }^{(14)}$.

Regarding blood pressure, in group (I), there was a slight increase in blood pressure just after intubation, then there was minimal decrease in the next readings but there was increase in mean of blood pressure after extubation. On the other hand, in group (II) there was a decrease in blood pressure after intubation and in the next readings. In addition, there was no increase in blood pressure after extubation in comparison with pre-operative reading. Also, in group (III), there was a decrease in blood pressure after intubation then there was a decrease in the next readings. There was no increase in blood pressure after extubation in comparison with pre-operative reading. Significant decrease in blood pressure was noticed in group (III) in 45, 60 minutes reading.

As regard the values of mean blood pressure in group (I), no fixed pattern of increase or decrease along course of operation. This means that $50 \mathrm{mg}$ magnesium could not maintain suitable blood level to induce hypotension but this did not occur in groups (II) and (III). There was rebound hypertension after stoppage of Mgso4 infusion in group (I) but this did not occurred in groups (II) and (III). Also, we observed significant decrease and fixation in blood pressure measurements in group (III) more than in group (II). This is in agreement with Elsharnouby and Elsharnouby ${ }^{(8)}$.

Also, similar result was approved by a dose response study done by Montazeri ${ }^{(15)}$ in order to identify the ideal dose of magnesium sulphate for optimum cardiovascular attenuation. A comparison of pulses and blood pressure before and after 5 minutes of intubation was done in groups who received $10 / 20 / 30 / 40 / 50 \mathrm{mg} / \mathrm{kg}$ magnesium sulphate and lignocaine $1.5 \mathrm{mg} / \mathrm{kg}$ was done. The study approved that 40 and $50 \mathrm{mg} / \mathrm{kg}$ of magnesium sulphate were most effective to abolish the intubation response.

Nevertheless, in the study, which has done by Dong and Daegu ${ }^{(16)}$ to search for if magnesium sulphate attenuates arterial pressure increase during laparoscopic cholecystectomy. They found no significant changes in cortisol blood level in magnesium group in comparison with the other one.

In the present study, we used mean of total dose of muscle relaxant needed to keep patient paralyzed guided by nerve stimulator and we found that group (III), which received $15 \mathrm{mg} / \mathrm{kg} / \mathrm{h}$ as continuous infusion dose needed the least amount of muscle relaxant less than group (II) and group (I). This difference was not statically significant as in study conducted by Morris and Richard ${ }^{(17)}$ in a prospective, randomized, double-blinded and placebo-controlled study where 42 patients were undergoing hernioplasty in balanced general anaesthesia, with sevoflurane, $\mathrm{N} 2 \mathrm{O}$, fentanyl and rocuronium.

They received intravenously, either magnesium sulfate $10 \%$, a bolus of $30 \mathrm{mg} \mathrm{kg}^{-1}$ before start of surgery and an infusion of $6 \mathrm{mg} \mathrm{kg}^{-1}$ $\mathrm{h}^{-1}$ over the entire operation period, or isotonic sodium chloride (control group). Intra- and postoperative analgesia were achieved with fentanyl. Results showed that fentanyl consumption intra-and postoperatively were significantly less in the magnesium group and with no adverse events. The requirements of muscle relaxants did not differ significantly between the groups. They concluded that magnesium sulfate in bolus and infusion doses lower than those used in previous studies is an effective adjuvant for perioperative analgesic management ${ }^{(17)}$.

Magnesium sulphate has been shown to reduce anaesthetic requirements. A randomized, placebo-controlled, double-blind study was done by Telci et al. ${ }^{(18)}$, which compared the use of total IV anaesthesia with propofol, remifentanil and vecuronium with and without magnesium. The total anaesthetic requirement was reduced in the magnesium group. Here are potential risks of using magnesium as it has multiple sites of action and can potentiate the actions of opioids and neuromuscular blocking drugs ${ }^{(17)}$.

The possible mechanisms of Mgso4 for reduction of the anaesthetic requirements include; antagonism of NMDA receptors in the CNS by magnesium, and reduction of catecholamine release by sympathetic stimulation, thus decreasing peripheral nociceptor sensitization or the stress response to surgery ${ }^{(18)}$.

\section{CONCLUSION}

Deliberated hypotension is very useful during surgery to decrease time and blood loss. Magnesium sulphate is one of the most useful techniques to induce hypotension during surgical operation. We suggest that using of magnesium sulphate in $40 \mathrm{mg} \mathrm{kg}$ as loading dose then continuous infusion at $15 \mathrm{mg} \backslash \mathrm{kg} \backslash \mathrm{h}$ is the most effective and safest technique. Magnesium sulphate is very useful agent to abolish stress response.

\section{REFERENCES}

1. Kassell NF, Boarin DJ, Olin JJ, Sprowell JA (1983): Cerebral and systemic circulatory effects of arterial 
hypotension induced by adenosine. J Neurosurgery, 58: $69-76$.

2. James M(1992): Clinical use of magnesium infusions. Anesth Analg., 74: 129-137.

3. Alan J, Gordon T (1995): Induced hypotension. In: a practice of anaesthesia 6th edition, ch. 39, pp: 234238.

4. Miller RD (1990): Hypotension. In Miller Anesthesia, edited by Ronald D. Miller, $6^{\text {th }}$ ed, vol, 3, Churchill livingstone inc, New York, pp: 1347.

5. Jeffery AF, Johon FB (1995): Sodium nitroprussid: Twenty years and counting. Aneth, analg., 9 (81): 15262.

6. Edward M,Maged S and Michael J(2006): clinical anathesiology .

https://trove.nla.gov.au/version/45742591

7. Ahlerling TE, Henderson JB et al. (1983): Controlled hypotensive anaesthesia to reduce blood loss in radical cystectomy for bladder cancer. J Urol., 129: 953.

8. El-sharnoby NM, El sharnoby MM (2006): magnesium sulphate as technique of hypotensive anesthesia. Br J Anesth., 96 (6): 727-31. 119.

9. Sanders GM, Sim KM (1998): Is it feasible to use magnesium sulphate as a hypotensive agent in oral and maxillofacial surgery? Ann Acad Med Singapore, 27: 780-5.

10. Crozier TA, Radke J, Weyland A et al. (1991): Haemodynamic and endocrine effects of deliberate hypotension with magnesium sulphate for cerebralaneurysm surgery. Eur J Anaesthesiol., 8: 115-21.

11. Akazawa $S$, Shimizu $R$, Nakaigawa $Y$, Ishii R, Ikeno
S, Yamato R (1997): Effects of magnesium sulphate on atrioventricular conduction times and surface electrocardiogram in dogs anaesthetized with sevoflurane. Br J Anaesth., 78: 75-80.

12. Ludbrook GL, James MF, Upton RN (1999): The effect of magnesium sulfate on cerebral blood flow velocity, cardiovascular variables, and arterial carbon dioxide tension in awake sheep. J Neurosurg Anesthesia, 11: 96-101.

13. Simpson $P$ (1992): Perioperative blood loss and its reduction the role of anesthetists. Br. J. Anaesthesia, 69: 498.

14. Smith G, Aitkenhead AR, Rowbotham DJ (2001): Hypotensive anaesthesia In 4th edition by Churchill livingstone.

15. Montazeri Y (2005): A dose-response study of magnesium sulphate in suppressing cardiovascular responses to laryngoscopy and endotracheal intubation. Journal of research in medicine sciences, 10 (2): 82-86.

16. Dong D, Daegu N (2009): Magnesium sulphate attenuates arterial pressure increase during laparoscopic cholecystectomy. Br J Anaesth., 103 (4): 484-9.

17. Morris R, Giesecke AH (1998): Potentiation of muscle relaxants by magnesium sulfate. South Med J., 61 (1): 25-8.

18. Telci L, Esen F, Akcora D, Erden T, Canbolat AT, Akpir K (2002): Evaluation of effects of magnesium sulphate in reducing intraoperative anaesthetic requirements. British journal of anaesthesia, 89 (4): 594-8. 